\title{
Development of Electronic Learning Media in Folklore Texts with Asahan Sociocultural Contents for Class X Students of SMK Negeri 2 Kisaran
}

\author{
Mira Sari Dewi ${ }^{1, *}$ Abdurahman Adisaputera ${ }^{2}$, Isda Pramuniati ${ }^{3}$ \\ ${ }^{1,2,3}$ Indonesian Language and Literature Education Study Program of Postgraduate School of Universitas Negeri \\ Medan, Indonesia 20221 \\ *Corresponding author.Email: Mirasaridewi2595@gmail.com
}

\begin{abstract}
The problem of this research is that the folklore learning process has not used electronic learning media and the students difficulties in identifying the values and characteristics contained in the folklore text. The research objectives were: (1) to determine the process of developing electronic learning media in Asahan sociocultural folklore texts, (2) to test the feasibility of electronic learning media in Asahan sociocultural folklore texts, and (3) to test the effectiveness of electronic learning media in Asahan's socioculturally charged folklore text. The research method chosen is the Research and Development (R\&D) research and development method which refers to the Borg and Gall development model. The results showed that: (1) the results of material expert validation included content feasibility with an average of $93.75 \%$, presentation feasibility with an average of $95.8 \%$, and language feasibility with an average of $95.1 \%$ in the very good category. The results of the media expert validation are in the very good category with an average percentage of $94.15 \%$, (2) the results of individual trials with an average of $86.8 \%$ in the very good category, the results of small group trials with an average of $89,12 \%$ in the very good category, and the results of the limited field test with an average of $91.27 \%$ (3) the results of the effectiveness of the learning media were obtained through student learning outcomes in the pretest and posttest. The average score at the pretest was $60 \%$ and at the posttest was $86.6 \%$. Thus, the electronic learning media in the Asahan sociocultural folklore text that has been developed is feasible to be used in the learning process.
\end{abstract}

Keywords: Electronic Learning Media, Text Folklore, Sociocultural.

\section{INTRODUCTION}

The development of cultural values can be done through various subjects in school, one of which is Indonesian language. Indonesian language subject matter can be used as material to develop cultural values that exist in the region. Therefore, teachers can add material that is considered appropriate to the environment and culture of students to develop the values contained in that culture.

One of the Indonesian language learning materials in the 2013 Curriculum that can be used to develop social and cultural values that exist in society is folklore. According to Hutomo (in Sundari, 2016: 19), folklore is a cultural expression of a society through spoken language that is directly related to sharing cultural aspects and the composition of the social values of the community.
Based on the results of interviews with two Indonesian language teachers at SMK Negeri 2 Kisaran, related to learning folklore there are weaknesses that need to be improved. First, the basic knowledge and skills in the field of literature by the teachers are limited. This resulted in the low level of appreciation of literature owned by students.

Second, there are still many students who have difficulty in understanding folklore texts well. Third, teachers still use learning media produced by the Ministry of Education and Culture in 2017 namely "Indonesian Language Revised 2017 Edition" and Solatif Books (Summative Practice Questions) Indonesian publisher Media Achievement.

Fourth, the learning that occurs is still centered on the teacher as the main source of knowledge and information for students. In response to this, teachers 
should be able to use folklore from their own area and take advantage of school facilities using electronic learning media. Electronic learning is an educational process that utilizes information and communication technology to bridge learning and learning activities (Prawiradilaga, D.S., 2013). By studying folklore from their own area, students can appreciate literature more and it is easy to identify the values that are a problem in learning folklore because it is closely related to their lives. In addition, you can also get to know the local socio-cultural (sociocultural) more closely. Vygotsky (in Komalasari (2010: 20) believes that one's way of thinking must be understood from its socio-cultural and historical background.

Based on the description above, a research was conducted that resulted in a product regarding the development of electronic learning media in the sociocultural content of Asahan folklore text for class X students of SMK Negeri 2 Kisaran.

\section{METHOD}

The type of research in this research is (Reserch and Development), because it is in accordance with the objectives to be achieved. Electronic learning media products (web) to develop learning in folklore texts. Development research can be grouped into three procedures, namely product development, product development procedures, and product testing.

While the research development model chosen is the Borg and Gall educational development. I Made Tegeh, I nyoman Jampel, and Ketut Pundjawa (2014:7) in developing, researchers adapted based on the Borg and Gall model on the grounds that the development design was used to develop a product.

\section{RESULTS AND DISCUSSION}

\subsection{The Process of Developing Electronic Learning Media on Folklore Texts}

The process of developing electronic learning media on folklore texts includes three stages, namely: Phase I needs analysis and literature survey. Needs analysis was obtained by distributing questionnaires, the results indicated that teachers and students really needed learning media and were interested in using electronic learning media in folklore text material. The results of the literature survey showed that when learning teachers used the Kemendikbud 2017 book, namely "Indonesian Language Revision 2017" and the Solative Book (Summative Practice Questions) Indonesian publisher Media Achievement, this was adjusted to the 2013 Curriculum. Phase II of initial product development. There are five steps used in the development of this initial product, namely (1) Analyzing content; (2) Analyze needs; (3) Ensuring the required facilities and infrastructure; (4) Develop learning scenarios; (5) Preparation of electronic learning media, namely on the sub-topic of Asahan folklore text. Phase III of product evaluation and testing is the core stage of the product development process. In this stage the product was tested on three groups of students and obtained an average score with the assessment criteria "very good". Then the final product in the form of learning media is ready to be used in learning Indonesian, especially in folklore text material in class X SMK.

\subsection{Feasibility of Electronic Learning Media on Folklore Texts}

The feasibility of electronic learning media in folklore texts is obtained from the results of validation carried out by material and design experts. Folklore text material with sociocultural content which is the substance in the developed media has the advantage of forming student character. The feasibility of learning media contains four components of the assessment, namely the feasibility of content, the feasibility of presentation, the feasibility of language and the feasibility of graphics. The components of content feasibility, presentation feasibility and language feasibility were obtained based on the validation of material experts, while the feasibility of graphics was obtained based on the validation results of design experts.

Revised and refined aspects based on data analysis and testing as well as input from material experts and design experts aim to explore common aspects in the process of developing a product. The aspects that are used in the assessment of material and design experts have a very good average.

After conducting a series of validations by material experts and design experts, the developed electronic learning media received feedback from the validator, then revisions were made based on the advice and input of experts to produce electronic learning media that were suitable for use. From the validation data as a whole,results validation expert material including the feasibility of contents with the average $93,75 \%$ with very good category, the feasibility of the presentation with the average $95,8 \%$ with very good category, and the feasibility of the language with the average $95,1 \%$ with very good category, the results of the validation of media experts shows that the media electronic learning in the text of the story of the people charged sociocultural Asahan located in the very good category with a percentage average $94,15 \%$, the score is in the very good category and is suitable for use as an electronic learning medium in schools. 


\subsection{The Effectiveness of Electronic Learning Media on Folklore Texts}

The effectiveness of electronic learning media on folklore text material is obtained from student learning outcomes. Student learning outcomes are known through a folklore text writing test. This test aims to the extent to which students improve in writing folklore texts. This test was conducted on 36 students of SMK Negeri 2 Kisaran. This test is also carried out in two stages, namely pretest and posttest.

The pretest was given before using the developed product and the posttest was given after using the developed product (media). The average value (mean) of student learning outcomes through the pretest is 60 and the posttest is 86.66. Based on these results, it can be seen that the average value of student learning outcomes increases with a difference of 26.66 increases.

The frequency of learning outcomes of folklore texts through the pretest showed that there were 3 students in the 50-52 grade interval with a percentage of $8.3 \%, 11$ students in the 53-55 grade interval with a percentage of $30.5 \%, 8$ students in the 59-61 grade interval with the percentage of $22.2 \%, 11$ students in the 65-67 grade interval with a percentage of $30.5 \%, 3$ students in the 68-70 grade interval with a percentage of $8.3 \%$, while the frequency distribution table for learning outcomes of folklore texts through the posttest shows that there is 1 student in the 75-77 interval with a percentage of $2.7 \%$, 6 students in the 78-80 grade interval with a percentage of $16.6 \%, 13$ students in the $84-86$ grade interval with a percentage of $36.1 \%$, there are no students who are in the 87-89 grade interval, 11 students in the 90-92 grade interval, with a percentage of $30.5 \%$ and 5 students in the 93-95 grade interval with a percentage of $13.8 \%$.

The calculation obtained from the product effectiveness test shows that the product developed in the form of electronic learning media in folklore texts is more effective than learning that does not use the media with an effectiveness of $86.66 \%$ while the effectiveness of learning that does not use the product developed (media) is $60 \%$.

\section{CONCLUSION}

The process of developing electronic learning media on folklore texts includes three stages, namely: Phase I needs analysis and literature survey. Needs analysis was obtained by distributing questionnaires, the results indicated that teachers and students really needed learning media and were interested in using electronic learning media in folklore text material. Phase II of initial product development. There are five steps used in the development of this initial product, namely (1) Analyzing content; (2) Analyze needs; (3) Ensuring the required facilities and infrastructure; (4) Develop learning scenarios; (5) Preparation of electronic learning media, namely on the sub-topic of Asahan folklore text. Phase III product evaluation and testing, is the core stage of the product development process

The feasibility of the developed electronic learning media is carried out by material experts and design experts. The material experts were carried out by AS and JF and the design experts were carried out by SMH and RM who are lecturers at the State University of Medan. The assessment of the feasibility of learning media is obtained from the percentage of the total number of questionnaires and interviews conducted with expert lecturers. The results of validation by material experts and design experts on every aspect and assessment indicators in the questionnaire as a whole obtained a very good rating. Thus, electronic learning media in folklore texts is declared feasible and can be used in the Indonesian language learning process.

The effectiveness of electronic learning media in folklore texts can be tested by looking at the differences in student learning outcomes that do not use electronic learning media with student learning outcomes using electronic learning media. Student learning outcomes are obtained from the provision of tests through pretest and posttest. Data analysis conducted on student learning outcomes who did not use electronic learning media obtained an average pretest score with the criteria of "enough" while those who did not use electronic learning media obtained an average score with the assessment criteria of "very good". This significant difference is stated to make a useful and effective contribution in improving the quality of student learning outcomes. It can be concluded that using electronic learning media can improve student learning outcomes, especially folklore text material.

\section{REFERENCES}

[1] Komalasari, Kokom. 2010. "Contextual Learning Concepts and Applications". Bandung: Refika Aditama.

[2] Prawiradilaga, et al. (Editor). 2013. Educational technology mosaic: Electronic learning. Jakarta: Kencana.

[3] Sundari. 2016. Indonesian Folklore. Surakarta: Eleven Maret University.

[4] Tegeh, I Made. 2014. Development Research Model. Yogyakarta: Graha Ilmu. 